\title{
Ministries of Foreign Affairs: A Crucial Institution Revisited
}

\section{Introduction}

The scholar who attends international conferences and reads regular publications on diplomatic studies and foreign policy analysis is confronted with one indisputable observation: If plenty of new academic research on contemporary diplomatic practices has emerged, few of those studies paradoxically focus on the comparative role of ministries of foreign affairs (MFAs). Thus, providing academic material to students on MFAs requires using chapters published in general textbooks; ${ }^{1}$ monographs based on single-country case studies; ${ }^{2}$ practitioners' accounts, which can be rather descriptive; ${ }^{3}$ and, finally, research published more than fifteen years ago. ${ }^{4}$ The goal of this special issue is to fill this gap in the literature by devoting a complete journal issue to the contemporary role of MFAs in diplomacy. The special issue is built on three components: original research articles, theoretical accounts and practitioners' accounts. Making a distinction between the three types of contributions is a clear choice to clarify who is speaking from where.

Four reasons explain the dearth of recent comparative studies on the role of MFAs in the world.

The first reason is a natural preference of scholars for new diplomatic institutions rather than classical ones. They consider it more exciting to work on new international institutions such as the European External Action Service operating in the context of the European Union, ${ }^{5}$ or nongovernmental

1 Berridge 2015; Constantinou, Kerr and Sharp 2016; Kerr and Wiseman 2018; Balzacq, Charillon and Ramel 2020.

2 Neumann 2012; Lequesne 2020.

3 Rana 2009, 2011.

4 Hocking 1999; Hocking and Spence 2003.

5 Morgenstern-Pomorski 2018; Gatti 2016; Balfour, Carta and Raik 2015. 
organisations (NGOs) in the field of human rights rather than MFAs. ${ }^{6}$ Social sciences are wrongly eager to forget institutions which incarnate continuity to focus exclusively on novelty. What is true for MFAs in the context of diplomatic studies is also valid for national parliaments in the context of comparative politics. ${ }^{7}$ In addition, MFAs are state institutions par excellence while, since the end of the Cold War, theories of International Relations (IR) have been fascinated by the emergence of non-state and transnational institutions. The number of studies devoted to international organisations and NGOS attests to the trend.

The second reason is because MFAs have largely lost their monopoly to make diplomacy to the benefit of other actors, both inside the state (head of government's offices, ministries of economics and defence, intelligence agencies) and outside the state (NGOs, international organisations, universities, celebrities). ${ }^{8}$ The demonopolisation of the MFAs' role leads scholars to consider too quickly that they have become marginal institutions in the making of diplomacy.

The third reason is because many states around the world are nondemocratic and opaque states in which the precise role of MFAs is difficult to understand. It therefore is not surprising that many diplomatic studies still focus empirically on the experience of liberal democratic states rather than non-democratic states, although the latter category counts major actors such as China and Russia where MFAs must be better analysed. ${ }^{9}$

The fourth reason comes from a true difficulty of scholarly research to observe from inside institutions such as MFAs, which remain dominated by the rules of secrecy and low transparency. ${ }^{10}$ If some scholars such as Iver B. Neumann and the author have been allowed to make observatory participations inside MFAs, such a research enterprise remains an exception. ${ }^{11}$ It is therefore not by chance that most of the knowledge we have on the internal practices of MFAs comes from the publications of practitioners, especially former ambassadors who write their memoirs when they retire. ${ }^{12}$ Memoirs and autobiographies are self-referential accounts based on interesting anecdotes but rarely on a deep analytical step back. Despite the general trend towards public diplomacy, MFAs remain institutions which resist the idea of being transformed into research objects by scholars, including in liberal democracies.

\footnotetext{
6 Brysk and Stohl 2019; Roeder and Simard 2015.

7 Costa 2016.

$8 \quad$ Cooper 2008; Neack 2013; Engelbrekt 2016.

$9 \quad$ Biberman 2011; Loh 2019; Ekman 2013.

10 Bjola and Murray 2016.

11 Lequesne 2019; Neumann 2012.

12 Araud 2019; Dobbin 2017.
} 
It is to overcome a certain renouncement of academic research to study MFAs with a comparative approach that we conceive this special issue. Five grounds can legitimise the nature of the enterprise.

First, it is because MFAs could not pretend anymore to hold the monopoly of state diplomacy that they have to be revisited in detail. MFAs must be understood in relation to a number of other actors-both state and non-statewhich are clearly in competition to formulate and implement diplomacy. Kim Olsen's contribution to this special issue shows how MFAs in France and Germany have difficulty in standing as powerful actors vis-à-vis the respective ministries of finance in the field of sanctions. More than ever, MFAs are part of a bureaucratic puzzle at the heart of the state based on competition and cooperation. If diplomacy, following James Der Derian's definition, consists of reducing the estrangement between diplomatic actors (mostly states) on the international stage, ${ }^{13}$ it also consists of many bureaucratic bargains and compromises inside the state. ${ }^{14}$ The domestic constraint plays a bigger role than in the past for MFAs because domestic publics want diplomats to be as accountable for their actions as any other state bureaucrats. In her contribution, former diplomat Emilie Bartonek details the importance for German Minister Frank-Walter Steinmeier to launch a review process in 2013 legitimising the MFA's actions among the German public. The Dutch MFA's report of 2013 on the modernisation of the diplomatic administration also highlights the expectations of the Dutch public to have more feedback on what diplomats are doing and how they are engaging public spending. ${ }^{15}$

Second, scholarly research must better understand who are the diplomats or the 'diplomatists', as Harold Nicolson calls them, working inside MFAs. ${ }^{16}$ We must not forget that, in many states, diplomats are still recruited according to purely political criteria, which consist of the proximity to governmental authorities. ${ }^{17}$ In states where examinations allow the entrance in diplomacy, the practices to attract candidates inside MFAs must be compared. ${ }^{18}$ Having diplomats who reflect societal diversity has become an issue for the MFAs in many democratic states. The gender issue, now well documented by research, has imposed itself for ten years in a profession which had been formally

\footnotetext{
13 Der Derian 1987.

14 Milner and Tingley 2015; Halperin 2006.

15 Dutch Ministry of Foreign Affairs 2013.

16 Nicolson 1954.

17 Haglund 2015; Hollibaugh 2015.

18 Neumann 2005.
} 
dominated by men. ${ }^{19}$ Based on a Swedish case study, Birgitta Niklasson shows in her contribution how women ambassadors now have the same access as men to formal relationships in diplomacy, but have more difficulties in breaking through the barriers of formality. Ethnic diversity in the recruitment of diplomats has become another issue for many MFAs in the world, as Christian Lequesne, Gabriel Castillo, Minda Holm, Walid Jumblatt Bin Abdullah, Halvard Leira, Kamna Tiwary and Reuben Wong demonstrate in their comparative article. Ethnic diversity not only is a strategic need for MFAs to support foreign policy priorities (for instance, Africa for Brazil during the presidency of Luiz Inàcio Lula da Silva), but also a necessity for filling a legitimacy gap in the domestic public sphere while MFAs are perceived disconnected from societal reality. All these new questions of diversity in the recruitment in MFAs need to be carefully analysed to escape the simple statement that diplomats are just men and pale upper class, full stop.

Third, MFAs stand at the centre of a lot of specific practices that diplomatic studies must capture to understand the modus operandi per se as well as their effects on decisions. ${ }^{20}$ If communication is not a new constitutive element of diplomacy, the use of internet and social networks have changed the tools which M FAs use to communicate. ${ }^{21}$ In his research article, Ilan Manor and Rhys Crilley shows how the Israeli MFA used social media during the 2014 Gaza War to legitimise Israel's foreign policy and also to de-legitimise the Hamas movement. Damien Spry analyses the effects of Facebook on the public diplomacy developed by several Asian and non-Asian MFAs in Asian locations. He demonstrates how poorer and smaller host Asian locations are more likely to pay attention to Facebook public diplomacy than richer and larger ones. If digital diplomacy has also become a well-documented practice in research, it is important to ask whether MFAs really control the information flows compared to other institutions such as intelligence services or specialised communication agencies. The practical piece written by Ambassador Casper Klynge, Mikael Ekman and NikolajJuncher Waedegaard highlights the reasons why the Danish MFA decided to create a TechPlomacy embassy to make sure that Danish diplomats remain at the centre of the new digital diplomacy as well as to attract private investments profitable to the Danish high-tech industry. Digital diplomacy also addresses the question of how diplomats use social media in their individual practice. Because they have blogs and Twitter accounts, can one say that diplomats are engaged in a new form of diplomacy, which takes more

\footnotetext{
19 Aggestam and Towns 2018; Cassidy 2017.

20 Cornut and Pouliot 2015; Sending, Pouliot and Neumann 2015.

21 Barston 2019; Hocking et al. 2013.
} 
seriously into consideration the feedback of the society? ${ }^{22}$ Alternatively, are social media just a new technical tool to diffuse unilateral messages close to what was referred to in the past as propaganda or information? ${ }^{23}$

Finally, scholarly research must address the question of how to better connect the study of MFAs to new theoretical debates on diplomacy and, largely, International Relations. Many recent studies rightly insist on the necessity to revisit diplomacy as a set of practices, assuming that theory must absolutely consider the social meaning that actors attach to what they are doing. ${ }^{24}$ Diplomacy exists only because actors themselves consider that it is a relevant practice. Research must therefore devote more time to theorising diplomacy from the inside perspective of the actors' mindsets. Good theorisation can be produced only after detailed fieldwork focussed on the agency, which is too often missing in IR theories. As Jason Dittmer shows in his theoretical contribution, however, considering human agency is a positive but not a sufficient step for theory. MFAs, as all institutions engaged in diplomacy, must also be considered as sites receptive to multi-layered non-human, material and environmental contexts. ${ }^{25}$ 'Assemblage', as Dittmer calls it, invites scholars to consider diplomacy as a process where intertwined human and non-human phenomena produce agential effects. Studying diplomacy from the prism of MFAs also reminds scholars that they need theories to explain a relational ontology. In his research article, Thierry Balzacq shows how the concept of 'grand strategy' can help to understand state diplomacy as a 'field', in the Bourdieusan sense of the term, in relation with other 'fields', be that security, intelligence or trade. Coming from a non-Western tradition, Yaqing Qin agrees with Balzacq that we must analyse M FAs as pivotal relators of a relational practice. He shows, however, that diplomats developing friendly relations with fellow diplomats to reduce estrangement is not a European invention. ${ }^{26}$ According to Qin, such a practice can be justified by the ancient Chinese political thinking as well.

First, future research on MFAs must focus on practices (both human and nonhuman) to understand the micropolitical factors at work in diplomacy, and

\footnotetext{
22 Cull 2019; Manor 2019.

23 De Keulenaar and Melissen 2018.

24 Lechner and Frost 2019; Pouliot 2016.

25 Dittmer 2017; Neumann 2013.

26 Anderson 1993; Datta-Ray 2016.
} 
more largely in foreign policy. Foreign policy analysis has invested much in the past ten years on the domestic determinants of foreign policy. It does not limit the study of foreign policy anymore to the effects or relations with the international system. ${ }^{27}$ Micropolitical factors emerge from their positions as hinges of macrostructural phenomena generally studied by IR theories, such as power relations, negotiations and alliances between states, but also with subnational entities, intergovernmental organisations, NGOS and individuals. As Dittmer writes in this special issue, this kind of analysis must contrast with the traditional macro and structural frameworks through which many IR theories are still produced, shifting away from the state as a monolithic unit of analysis towards a 'diplomatic system' where MFAs represent one body of politics. In his research, Dittmer used archives of the British Foreign Office from the 18th to the late 2oth century. To analyse the more contemporary period, research can use other sources such as public documents produced by MFAs, semi-direct interviews and observatory participation. For sure, practice theory without a solid empirical basis has no sense. There is even a risk that some practice theorists might see it as only a set of abstract concepts and, thus, reproduce in the future the same kind of broad generalities without carefully observing diplomatic agents and sites. ${ }^{28}$ In this case, practice theory has little interest.

Second, further research on MFAs must investigate the 'material circulations ... that produce political subjectivities' within diplomacy. ${ }^{29}$ We must carefully study the exchange of written notes, gifts and food, but also the design of negotiating sites, not per se but to assess their effects on diplomatic outcomes. Materialities in the daily routines of MFAs, such as the writing style of cables, the positioning of actors in meeting rooms and the organisation of meals, are fundamental elements for understanding diplomacy. The study of the Diplomatic Protocol, a set of codified rules to facilitate order in estranged relationships, is a promising field for diplomatic studies. Sociology of rituals, such as Erving Goffmann's work, is a relevant source of inspiration for scholars who want to understand the political meaning of Diplomatic Protocol. ${ }^{30}$

Third, further research must consider the sociology of elites and produce accounts of who are the diplomats and where do they come from? In Western democracies, diplomats in the 21st century are socially more diverse than they were in the $195 \mathrm{Os}^{31}$ but, surprisingly, we have little solid research about the

\footnotetext{
$27 \quad$ Kaarbo 2015.

28 Bueger and Gadinger 2014.

29 Dittmer 2017, 3.

$30 \quad$ Goffmann 1967; Balzacq 2020.

$31 \quad$ Galtung and Ruge 1965.
} 
evolutional patterns. The study of the social background of diplomats inside MFAs is typically a research theme, which can be usefully invested by quantitative studies. It would be misleading to think that the diversification of diplomatic agency is a phenomenon limited to the West. We can observe similar trends in India as a result of the reservation policy benefitting candidates coming from low-caste backgrounds, or in Iran where children of disabled Iran-Iraq War veterans have been granted special advantages to enter higher education institutions that lead to recruitment in the Iranian MFA. ${ }^{32}$ But in the end, does this social diversification influence diplomatic outcomes? We must also investigate further the changing role of ambassadors. If all we have are memoires published by retired ambassadors, little critical and comparative work will exist on the ambassadorial function outside of works produced by historians. ${ }^{33}$ All of this constitutes challenging questions on which we must know more.

Fourth, a domain for future research is the relationship between MFAs and domestic (not international) politics. Whatever the nature of a political regime, MFAs are state bureaucracies that have to bargain with politicians. However, the relationships of diplomats with politicians do not follow the same path in all countries. The Brazilian MFA, Itamaraty, was created after the Portuguese decolonisation as a corporatist bureaucracy and managed through history to remain as autonomous as possible from the state executive. Autonomy is considered inside Itamaraty as the normal result of specific skills and expertise. ${ }^{34}$ When President Lula came to power in 2003 and decided to be proactive in diplomacy, Brazilian diplomats denounced an attempt to 'politicise' their bureaucratic autonomy. The criticism of Brazilian diplomats is even harsher since the 2019 election of President Jair Bolsonaro, who has deliberately decided to brush under the carpet several influential diplomats. When the conservative Law and Justice party (PiS) won the 2015 election in Poland, the new government decided to dismiss most of the career ambassadors and to appoint non-career ambassadors on the basis of their closeness to the new ruling party. ${ }^{35}$ Such a spoils system, consisting of distributing ambassadorships in major countries to non-career diplomats, has existed for a long time in the United States. ${ }^{36}$ It gives to us ambassadors a 'political touch', which does not exist to the same extent for West European career ambassadors.

32 Hansel, Khan and Levaillant 2017; Beaud forthcoming.

33 Kessler 2012; Rana 2013.

34 Vaïsse and Saint-Geours 2019.

35 A study of the Polish case after the 2015 election of PiS is missing in the literature.

36 Haglund 2015 . 
Three additional questions can therefore be further researched regarding the relationship of MFAs to domestic politics. First, non-democratic states must not be forgotten. In single-party regimes such as China or Vietnam, are MFAs just the subordinates of Communist Party Central Committees, or are they able to save a form of autonomy based on a specific expertise? Second, what is the effect of party politics inside MFAs, whatever the nature of the political regime? Third, the previous question must be linked to the rise of populist leaders in democracies, who do not like diplomats to be identified as traitors and diverted elites. To what extent do populist leaders such as Donald Trump in the United States, Jair Bolsonaro in Brazil and Viktor Orbán in Hungary ignore their MFAs in the conduct of diplomacy? What is the capacity of diplomats in these respective countries to react and bypass populist leaders thanks to their established practices and networks in the international system? ${ }^{37}$ All of these questions related to the diplomat-politician nexus have to be theorised on a comparative basis. Again, research should not be limited to the nature of the relations and tensions, but also evaluate the effect of turf wars on the diplomatic outcomes produced by states.

MFAs are definitely not at all old-fashioned objects for diplomatic studies. They remain institutions at the heart of the reflection on contemporary diplomacy, offering much potential for diplomatic studies. To provide good theoretical accounts, research on MFAs must concentrate on the study of practices and avoid two traps in parallel: focusing exclusively on single-country cases and forgetting the case of non-democratic countries. Diplomatic studies cannot remain a field of work by comparing only Western experiences. It absolutely must invest more in the relationship between diplomacy and authoritarianism, with a special emphasis on countries such as Algeria, Pakistan and Russia where MFAs are doing mostly 'window dressing' while the real actors of diplomacy are clearly elsewhere in the state, especially in intelligence services and armed forces staffs. Diplomatic studies must investigate more about how diplomacies are constrained by these practices of anti-diplomacy in many countries of the world. ${ }^{38}$

\section{Bibliography}

Aggestam, Karin and Ann E. Towns, eds. Gendering Diplomacy and International Negotiation (Basingstoke: Palgrave Macmillan, 2018).

37 Cooper 2019; Plagemann and Destradi 2019.

38 Der Derian 1992. 
Anderson, M.S. The Rise of Modern Diplomacy: 1450-1919 (London: Routledge, 1993).

Araud, Gérard. Passeport diplomatique: Quarante ans au Quai d'Orsay (Paris: Grasset, 2019).

Balfour, Rosa, Caterina Carta and Kirsti Raik eds. The European External Action Service and National Foreign Ministries: Convergence and Divergence (Abingdon: Ashgate, 2015).

Balzacq, Thierry. 'Rituals and Diplomacy'. In Global Diplomacy: An Introduction to Theory and Practice, eds. Thierry Balzacq, Frédéric Charillon and Frédéric Ramel (Abingdon: Palgrave Macmillan, 2020), 111-122.

Balzacq, Thierry, Frédéric Charillon and Frédéric Ramel eds. Global Diplomacy. An Introduction to Theory and Practice (Abingdon: Palgrave Macmillan, 2020).

Barston, Ronald Peter. Modern Diplomacy (London: Routledge, 2019).

Beaud, Guillaume. Mutations des dispositifs de recrutement et de formation des élites diplomatiques et rapports de force politico-bureaucratiques dans l'Iran postrévolutionnaire, Master's Thesis (Doctoral School, Sciences Po, forthcoming).

Berridge, G. Diplomacy: Theory and Practice (Basingstoke: Palgrave Macmillan, 2015).

Biberman, Yelena. 'The Politics of Diplomatic Service Reform in Post-Soviet Russia'. Political Science Quarterly 126 (4) (2011), 669-68o.

Bjola, Corneliu and Stuart Murray, eds. Secret Diplomacy: Contexts and Cases (London: Routledge, 2016).

Brysk, Alison and Michael Stohl. Contesting Human Rights: Norms, Institutions and Practice (Cheltenham: Edward Elgar, 2019).

Bueger, Christian and Franck Gadinger. International Practice Theory: New Perspectives (Basingstoke: Palgrave Macmillan, 2014).

Cassidy, Jennifer, ed. Gender and Diplomacy (London: Routledge, 2017).

Constantinou, Costas M., Pauline Kerr and Paul Sharp, eds. The SAGE Handbook of Diplomacy (London: Sage, 2016).

Cooper, Andrew F. Celebrity Diplomacy (London: Routledge, 2008).

Cooper, Andrew F. 'The Disintermediation Dilemma and Its Impact on Diplomacy: A Research Agenda for Turbulent Times'. Diplomacy and Statecraft 30 (4) (2019), 799-807.

Cornut, Jérémie and Vincent Pouliot. 'Practice Theory and the Study of Diplomacy: A Research Agenda'. Cooperation and Conflict 50 (3) (2015), 297-315.

Costa, Olivier. 'Legislative Politics, Going International, while Staying Native'. In Oxford Handbook of French Politics, eds. R. Elgie, E. Grossman, and E. Mazur (Oxford: Oxford University Press, 2016), 198-219.

Cull, Nicholas. Public Diplomacy: Foundations for Global Engagement in the Digital Age (Cambridge: Polity, 2019).

Datta-Ray, Deep K. The Making of Indian Diplomacy: A Critique of Eurocentrism (Oxford: Oxford University Press, 2016). 
De Keulenaar, Emilie V. and Jan Melissen. 'Critical Digital Diplomacy and How Theory Can Inform Practice'. In New Realities in Foreign Affairs: Diplomacy in the 21st Century, ed. Volker Stanzel (Baden-Baden: Nomos, 2018), 63-70.

Der Derian, James. On Diplomacy: A Genealogy of Western Estrangement (Oxford: Blackwell, 1987).

Der Derian, James. Antidiplomacy: Spies, Terror, Speed and War (Oxford: Blackwell, 1992).

Dittmer, Jason. Diplomatic Material: Affect, Assemblage and Foreign Policy (Durham: Duke University Press, 2017).

Dobbin, James F. Foreign Service: Five Decades on the Frontline of American Diplomacy (Washington, DC: Brookings Institution, 2017).

Ekman, Alice. The Shaping of National Diplomatic Practices: Contemporary Chinese Diplomacy as a Case Study, Dissertation in political science (Paris: Sciences Po, 2013). Dutch Ministry of Foreign Affairs. Modernising the Diplomatic Service, Progress Report 2013 (The Hague: Dutch Ministry of Foreign Affairs, 2013).

Engelbrekt, Kjell. High-Table Diplomacy: The Reshaping of International Security Institutions (Washington, DC: Georgetown University Press, 2016).

Galtung, Johan and Mari Holmboe Ruge. 'Patterns of Diplomacy'. Journal of Peace Research 2 (2) (1965), 101-135.

Gatti, Mauro. European External Action Service: Promoting Coherence and Coordination (Leiden: Brill, 2016).

Goffmann, Erving. Interaction Ritual: Essays on Face-to-Face Behavior (New York: Anchor Books, 1967).

Haglund, Evan. 'Striped Pants versus Fat Cats: Ambassadorial Performance of Career Diplomats and Political Appointments'. Presidential Studies Quarterly 45 (4) (2015), $653-678$.

Halperin, Morton H. Bureaucratic Politics and Foreign Policy (Washington, DC: Brookings Institution, 2006).

Hansel, Misha, Raphaëlle Khan and Mélissa Levaillant, eds. Theorizing Indian Foreign Policy (London: Routledge, 2017).

Hocking, Brian, ed. Foreign Ministries: Change and Adaptation (New York: St. Martin's Press, 1999).

Hocking, Brian, Jan Melissen, Shaun Riordan and Paul Sharp. 'Integrative Diplomacy for the 21st Century'. In China International Strategy Review (Beijing: Center for International and Strategic Studies, 2013), 53-88.

Hocking, Brian and David Spence, eds. Foreign Ministries in the European Union: Integrating Diplomats (New York: Palgrave Macmillan, 2003).

Hollibaugh, Gary B. Jr. 'The Political Determinants of Ambassadorial Appointments'. Presidential Studies Quarterly 45 (3) (2015), 445-466. 
Kaarbo, Juliet. 'A Foreign Policy Analysis on the Domestic Politics Turn in IR Theory'. International Studies Review 17 (2) (2015), 189-216.

Kerr, Pauline and Geoffrey Wiseman, eds. Diplomacy in a Globalizing World: Theories and Practices (Oxford: Oxford University Press, 2018).

Kessler, Marie-Christine. Les ambassadeurs (Paris: Presses de Sciences Po, 2012).

Lechner, Silviya and Mervyn Frost. Practice Theory and International Relations (Cambridge: Cambridge University Press, 2019).

Lequesne, Christian. 'Studying Diplomatic Practices through the Lens of Direct Observation' (London: Sage Research Method Cases, 2019).

Lequesne, Christian. Ethnographie du Quai d'Orsay (Paris: CNRs Editions/Biblis, 2020). Loh, Dylan мн. 'Institutional Habitus, State Identity, and China's Ministry of Foreign Affairs'. International Studies Review (2019), 1-24.

Manor, Ilan. The Digitalization of Public Diplomacy (Basingstoke: Palgrave Macmillan, 2019).

Milner, Helen V. and Dustin Tingley. The Domestic Politics of American Foreign Policy (Princeton: Princeton University Press, 2015).

Morgenstern-Pomorski, Henrik. The Contested Diplomacy of the European External Action Service: Inception, Establishment and Consolidation (London: Routledge, 2018).

Neack, Laura. The New Foreign Policy: Complex Interactions, Competing Interests (Lanham, MD: Rowman and Littlefield, 2013).

Neumann, Iver B. ‘To Be a Diplomat'. International Studies Perspectives 6 (1) (2005), 72-93.

Neumann, Iver B. At Home with the Diplomats inside a European Ministry of Foreign Affairs (Ithaca: Cornell University Press, 2012).

Neumann, Iver B. Diplomatic Sites: A Critical Enquiry (London: Hurst, 2013).

Nicolson, Harold. The Evolution of Diplomatic Method (London: Cassell, 1954)

Plagemann, Johannes and Sandra Destradi. 'Populism and Foreign Policy: The Case of India'. Foreign Policy Analysis 15 (2) (2019), 283-301.

Pouliot, Vincent. International Pecking Orders: The Politics and Practice of Multilateral Diplomacy (Cambridge: Cambridge University Press, 2016).

Rana, Kishan S. Asian Diplomacy: The Foreign Ministries of China, India, Japan Singapore and Thailand (Baltimore: Johns Hopkins University Press, 2009).

Rana, Kishan S. 21st Century Diplomacy: A Practitioner's Guide (New York: Continuum Group, 2011).

Rana, Kishan S. The Contemporary Embassy: Paths to Diplomatic Excellence (Abingdon: Palgrave Macmillan, 2013).

Roeder, Larry and Albert Simard. Diplomacy and Negotiation for Humanitarian NGOs (New York: Springer, 2015). 
Sending, Ole Jacob, Vincent Pouliot and Iver B. Neumann, eds. Diplomacy and the Making of World Politics (Cambridge: Cambridge University Press 2015).

Vaïsse, Maurice and Yves Saint-Geours, eds. Diplomaties étrangères en mutation (Paris: Pédone, 2019).

\section{Christian Lequesne}

is Professor of Political Science, Sciences Po (CERI), Paris, and a Regular Visiting Professor at the Libera Università Internazionale degli Studi Sociali (LUISS) University, Rome, and the Diplomatic Academy, Vienna. He was formerly Sciences Po-LSE Professor at the European Institute of the London School of Economics and Political Science (LSE). He is also Co-Editor-in-Chief of the European Review of International Studies. He has published and edited twenty books on European Union politics, and is now working on the sociology of diplomatic practices. His last book published in France was an ethnographic research on the practices of French diplomats.

Christian Lequesne ${ }^{39}$

Sciences Po (CERI), Paris, France

christian.lequesne@sciencespo.fr

39 The author thanks Marcus Holmes and Jan Melissen for their kind support of the editorial work, and Barbara Teixeira de Sousa Sénécaut for her research assistance. He also thanks Sciences Po's 'Fonds Tremplin à l'Activité Scientifique' for financing two meetings with the journal editor. 